\title{
COMMENTARY ON COVID-19 A THREAT TO WILDLIFE MANAGEMENT
}

\author{
DENNIS TEN CHOON YUNG ${ }^{1}$ AND MOHD TAJUDDIN ABDULLAH*2,3,4
}

\begin{abstract}
${ }^{1}$ Department of Wildlife and National Parks, KM 10, Jalan Cheras, 56100 Kuala Lumpur, Malaysia. ${ }^{2}$ Institute of Tropical Biodiversity and Sustainable Development, ${ }^{3}$ Faculty of Fisheries and Food Science, Universiti Malaysia Terengganu, 21030 Kuala Nerus, Terengganu, Malaysia. ${ }^{4}$ Fellow Academy of Sciences Malaysia, Level 20, West Wing, Tingkat 20, Menara MATRADE, Jalan Sultan Haji Ahmad Shah, 50480 Kuala Lumpur, Malaysia.
\end{abstract}

*Corresponding authors: Dennis Ten Choon Yung, email: dennis@wildlife.gov.my
Mohd Tajuddin Abdullah, email: abdullahmt@gmail.com
Submitted finaldraft: 3 August2020 Accepted: 10 August2020

http://doi.org/10.46754/jssm.2021.04.001

\begin{abstract}
The COVID-19 virus is a zoonotic disease, an infectious disease caused by a pathogen (an infectious agent, such as a bacterium, virus, parasite or prion) that has jumped from an animal (usually a vertebrate) to a human. It was declared a pandemic by World Health Organization (WHO) on January 30, 2020. The COVID-19 virus is also a zooanthroponosis, that can be transmitted from human to animals. Malaysia has seven wild cats' species and five mustelids which can be found in the forests of Peninsular Malaysia as well as in captivity, in zoos and conservation facilities. Human beings have the potential to spread the COVID-19 virus to wild mustelids and big cat species, which may threaten its populations in Peninsular Malaysia. The authorities must respond swiftly during the zoonotic phase and post-zoonotic contingency phase, with stringent policies and guidelines to control the spread of the disease into natural forest habitats that may threaten the mustelids and cat populations.
\end{abstract}

Keywords: Biodiversity, COVID-19, Malaysia, tropical rain forest, SARS-CoV-2, zooanthroponosis, zoonotic diseases.

\section{Introduction}

In the last decade, there were 15 diseases that represented potential international threats which needed an immediate response by the World Health Organization (WHO, 2018). The latest disease to make the list was the COVID-19 virus, which was declared a pandemic by the World Health Organization on January 30, 2020 (WHO, 2020a). The SARS-CoV-2 virus is responsible for COVID-19 disease (OIE, 2020a). The COVID-19 virus is classed as a zoonosis disease, an infectious disease caused by a pathogen (an infectious agent, such as a bacterium, virus, parasite or prion) that has jumped from an animal (usually a vertebrate) to a human and is believed to have originated from the horseshoe bat (Rhinolophus spp) (Shi et al., 2020) as a reservoir (Zhou et al., 2020) and transmitted to human beings using a Malayan Pangolin (Manis javanica) as host (Lam et al., 2020; Xiao et al., 2020). The transmission of the COVID-19 virus then moved from person to person through direct and indirect contact (WHO, 2020a), and this is known as being an anthroponosis disease, a pathogen, virus or bacterium that can be transmitted from humans to animals.

The COVID-19 pandemic has infected $15,785,641$ individuals in 215 countries and territories, including Malaysia, which recorded 8,884 virus-positive individuals as of July 26, 2020 (WHO, 2020c). Malaysia has continued to control and mitigate the spread of the disease by implementing various measures, including the movement control order (MCO), which started on March 18, 2020. The MCO aims to stop the disease chain by limiting human physical contact. At the time of writing this paper, the order has been extended till August 31, 2020.

While Malaysians were fighting to stop the spreading of COVID-19 pandemic in the country, the country was shocked by the news that four Malayan tigers and three African lions at the Bronx Zoo, in New York tested positive for the COVID-19 virus on April 5, 2020. It is believed the zoo workers infected those cats' (Abdullah et al., 2020; Daly, 2020). Bronx Zoo had reported that all seven cats were slowly 
recovering on April 22, 2020 (WCS, 2020). The transmission of the disease from humans to animals indicates that the COVID-19 virus can reverse the zoonotic disease transmission vector (zooanthroponosis) (Abdullah et al., 2020).

The anxiety over the disease continues as (Shi et al. 2020) reported that ferrets and other cat species are also susceptible to the SARSCoV-2 virus. The news is very disturbing to conservationists of mustelids and big cat species, especially those working with the Malayan Tiger.

It is speculated that wildlife is a reservoir of emerging and reemerging zoonotic diseases. Studies also indicate that the COVID-19 virus can also be transmitted back from human beings to wildlife (Daly, 2020; Kim et al., 2020; Shi et al., 2020).

Therefore, it is crucial to explore the possibility and extent to which emerging infectious disease such as the COVID-19 virus would threaten wildlife resources in Peninsular Malaysia. Measures need to be put in place to better prepare for the next wave of pandemics be it COVID-19 or something else. In this commentary, we will discuss the potential threat of COVID-19 to the conservation of Malaysian wildlife and the way forward post-COVID-19.

\section{Methods}

The author utilised all the available sources from Web of Science and Scopus databases as well secondary data from the Department of Wildlife and National Parks (DWNP) in the form of guidelines annual reports provided online on the departments' official web.

The data extracted from these reports, was used to make a qualitative interpretation of the needs of this commentary.

\section{Threat to Wild Cat Populations}

Cats (Felidae) and ferrets (Mustelidae) are both highly susceptible to the COVID-19 infection (Shi et al., 2020). There are seven wild cats species in Peninsular Malaysia, namely the Malayan Tiger (Panthera tigris jacksoni), Leopard (Panthera pardus), Clouded leopard (Neofelis nebulosa) (Figure 1), Asian golden cat (Catapuma temminckii), Marbled cat (Pardofelis marmorata), Leopard cat (Prionailurus bengalensis), Flat-headed cat (Prionailurus planiceps) (DWNP, 2017) that are most at risk.

Among mustelids five species, namely the Hairy-nosed otter (Lutra sumatrana), Oriental small-clawed otter (Aonyx cinereus), Smooth otter (Lutrogale perspicillata), Yellow-throated



Figure 1: Clouded leopard (Neofelis nebulosa) foraging in a forest can be potentially susceptible to COVID-19 (Photograph CDWNP-WCS) 
marten (Martes flavigula) and the Malayan weasel (Mustela nudipes) (DWNP, 2017) are also equally at risk of a COVID-19 infection.

All seven cats species and five mustelids species are distributed evenly in protected areas (i.e. national parks, forest reserves, eco-parks, state park forests ) and non-protected forest areas (DWNP, 2017).

The wild population of Malayan Tigers was estimated at less than 200 individuals in 2018 (DWNP, 2020b). All seven cat species and five mustelid species are gazetted as Totally Protected species under the Wildlife Conservation Act 2010 [WCA 2010] (Kawanishi, 2015; DWNP, 2017) and have various levels of conservation status on the Red List, 2017 (Table 1).

In 2018, DWNP recorded 605,898 tourists had visited eight eco-tourist sites managed by the department (DWNP, 2018). The ecotourist sites include the tri-state National Park of Terengganu, Pahang and Kelantan. While
$5,115,481$ tourists, have visited eco-park forests and State Park forests nationwide in 2015 (FDPM, 2018b). From the statistics, it is estimated that at least 5.5 million tourists visited natural forests in the country annually. These tourists could potentially carry the SAR-CoV-2 virus and spread it to the wild cat population, including the Malayan Tiger, at these parks.

Malaysia lost the critically endangered Javan rhinoceros (Rhinoceros sondaicus) not too long ago (DWNP, 2017). This sad state of affairs was repeated recently as the Sumatran rhinoceros (Dicerorhinus sumatrensis) also went extinct (Havmøller et al., 2016; Bittel, 2019). Malaysian conservationists would certainly be very sad if the wild cat and other COVID-19 susceptible species populations are decimated or lost due to the COVID-19 virus.

The Malaysian management authority has implemented various in situ action plans (DWNP, 2008) and ex situ conservation efforts

Table 1: The wild cats' species and mustelids species in Peninsular Malaysia

\begin{tabular}{|c|c|c|c|}
\hline No. & & WCA 2010 & $\begin{array}{c}\text { Red List Status, } \\
2017\end{array}$ \\
\hline & A. Wild Cats' Species & & \\
\hline 1 & Malayan Tiger (Panthera tigris jacksoni) & $\mathrm{TP}$ & $\mathrm{CR}$ \\
\hline 2 & Leopard (Panthera pardus) & $\mathrm{TP}$ & $\mathrm{EN}$ \\
\hline 3 & Clouded leopard (Neofelis nebulosa) & $\mathrm{TP}$ & NT \\
\hline 4 & Asian golden cat (Catapuma temminckii) & $\mathrm{TP}$ & NT \\
\hline 5 & Marbled cat (Pardofelis marmorata) & $\mathrm{TP}$ & $\mathrm{LC}$ \\
\hline 6 & Leopard cat (Prionailurus bengalensis) & $\mathrm{TP}$ & NT \\
\hline \multirow[t]{2}{*}{7} & Flat-headed cat (Prionailurus planiceps) & $\mathrm{TP}$ & DD \\
\hline & B. Species under family Mustelidae & & \\
\hline 1 & Hairy-nosed otter (Lutra sumatrana) & $\mathrm{TP}$ & $\mathrm{EN}$ \\
\hline 2 & Oriental small-clawed otter (Aonyx cinereus) & $\mathrm{TP}$ & NT \\
\hline 3 & Smooth otter (Lutrogale perspicillata) & $\mathrm{TP}$ & $\mathrm{LC}$ \\
\hline 4 & Yellow-throated marten (Martes flavigula) & $\mathrm{TP}$ & NT \\
\hline 5 & Malayan weasel (Mustela nudipes) & TP & $\mathrm{LC}$ \\
\hline
\end{tabular}

Notes:

WCA 2010 - Wildlife Conservation Act 2010

Red List Status 2017 - Red List of Mammals for Peninsular Malaysia (DWNP, 2017)

TP - Totally Protected, WCA 2010; CR - Critically endangered; EN - Endangered;

VU - Vulnerable; NT - Near threatened; LC - Least concern; DD - Data deficient 
to revive the Malayan Tiger population in the wild (Ten et al., in review). Malaysia has lost $60 \%$ of its wild Malayan tiger population since 1990 (Ten et al., in review).

The tiger exists on the Malaysian coat of arms, and is also a symbol of strength and royal power in the country (DWNP, 2008). Losing the wild Malayan tiger population in Peninsular Malaysia mean there will be no more wild Malayan tigers in our forests. Malaysia cannot afford to lose the Malayan tiger wild population to the COVID-19 virus.

\section{Threat to the Indigenous Species}

The earth is suffering the sixth extinction (Ceballos et al., 2015). The loss of majority of species in the relatively short time which was caused by a catastrophic natural event is known as the Sixth Mass Extinction (Ceballos et al., 2017). Academicians and experts have provided evidence in the form of records that illustrate that a drastic reduction and significant changes in the existence of animal species mimicking the sixth extinction is brewing in Malaysia (Abdullah et al., 2017). The confounding factors for the species extinction in Malaysia, among others, are the destruction of ecosystems, rampant unchecked wildlife trade and diseases (Abdullah et al., 2017).

Malaysia, is proud of its mega diversity Peninsular Malaysia has recorded 223 species of mammals (DWNP, 2017). The country has been using the big five mammals as iconic species to promote and describe its wildlife diversity and conservation works.

The big five mammals that the country uses to promote its wildlife diversity are the Asian elephant (Elephas maximus), Sumatran rhinoceros (Dicerorhinus sumatrensis), Malayan gaur (Bos gaurus hubbacki), Malayan tapir (Tapirus indicus) and Malayan tiger (Panthera tiger jacksoni).

All of which are classed as Totally Protected species under WCA 2010 but with different Malaysian Red List conservation statuses.
The Malayan tiger is listed as critically endangered, Malayan gaur and tapir are endangered, while the Asian elephant is listed as vulnerable (DWNP, 2017).

In Malaysia, the big five mammals are experiencing a decrease in population numbers due to confounding factors including - ecosystem destruction and wildlife trade (Ten, 2006; Saaban et al., 2011; Magintan et al., 2012; Kawanishi, 2015; Abdullah, 2016). Disease is the third confounding factor, which clearly indicates that extinction of these species is likely, and this may severely impact current wildlife populations.

Malayan Tigers are susceptible to zoonotic disease as the Malayan Tiger population had been infected with Canine distemper in 2019 (DWNP, 2019) and had subsequently been infected by the COVID-19 virus in 2020 (Daly, 2020). Captive Malayan gaur were affected by the foot and mouth disease in 2008 (The Star, 2008).

The bacterial infection (Trypanosomes) (Vellayan et al., 2004) and Escherichia coli combined with a Klebsiella infection (Ahmad et al., 2013) is believed to be responsible for wiping out the entire captive population of Sumatran rhinoceros at the Sungai Dusun Rhino Conservation Centre, Selangor in 2003.

Seven captive Malayan tapirs died at the centre due to Escherichia coli and Trypanosomes in 2010 (NRE, 2010; Ahmad et al., 2013). .

On that note, we have observed the three confounding factors of the sixth extinction in Malaysia, thus, are we on the edge the sixth extinction or it has started? This hypothesis needs a lot more research, deductive reasoning and debate.

In 2020 Malaysia's population was 32.73 million, with a growth rate of $0.6 \%$ (DSM, 2020). However, the country's forest reserves keep on decreasing, for instance, Peninsular Malaysia's forest cover has declined from 7.16 million hectares in 1988 (Shevade et al., 2017 ) to 5.76 million hectares in 2017 (FDPM, 2018a). Generally, a smaller forest size means 
human populations are moving closer to wildlife sanctuaries and are sharing parts of the land.

This human-wildlife proximity is indicated by the consistently high complaints of the human-wildlife conflict cases in Peninsular Malaysia (Table 2).

Human-wildlife conflicts have facilitated the spread of diseases from human to animals and vice-versa. In other words, the indigenous wildlife is vulnerable and at high risk of being infected by human beings and vice-versa (Ta et al., 2014; Law, 2018).

Table 2: The human-wildlife conflict complaints in Peninsular Malaysia

\begin{tabular}{llc}
\hline No. & Year & $\begin{array}{c}\text { Number of human-wildlife } \\
\text { conflict complaints (cases) }\end{array}$ \\
\hline 1. & 2010 & 9,286 \\
2. & 2011 & 8,031 \\
3. & 2012 & 5,602 \\
4. & 2013 & 5,677 \\
5. & 2014 & 6,484 \\
6. & 2015 & 6,256 \\
7. & 2016 & 6,769 \\
8. & 2017 & 7,451 \\
9. & 2018 & 7,925 \\
10. & 2019 & 9,755 \\
\hline
\end{tabular}

\section{Good Wildlife Practice}

The One Health concept is a collaborative approach to understanding the risks to the health of humans, animals and the ecosystem (OIE, 2020b).

The Malaysia One Health University Network (MyOHUN) was designed to facilitate collaboration among a cross-sector of professionals, which would help them respond to emerging infectious and zoonotic diseases (MyOHUN, 2016).

MyOHUN in their manual entitled One Health Manual On Handling Zoonotic Disease Outbreaks in Malaysia mentioned that securing funding; an investment framework, policies and processes; and governance are among the ways to handle a zoonosis outbreak moving forward (Andrew et al., 2017).

We recommend some good wildlife practices consistent with the One Health manual on handling zoonotic disease outbreaks in Malaysia to ensure the sustainability of the wildlife populations for our future generations.

The suggestions based on the manual are as follows:

\section{a) Stringent Policy and Guideline in Managing Species}

The wild cats and mustelids are susceptible to the COVID-19 virus (Shi et al., 2020), but the Malayan tiger species is the only one confirmed to have been infected with the COVID-19 virus (Daly, 2020; WCS, 2020). The DWNP has issued 8,334 licenses to hunt wildlife in the forest and 21,345 licenses to keep wildlife (DWNP, 2018).

The licensees naturally will carry out hunting in the forest, and they are the potential disease carriers. Until we understand the impact of the COVID-19 pandemic on the mustelids and wild cat populations, the authorities should consider imposing additional steps to the standard operating procedure of obtaining these licenses for instance requiring health certificates for hunting license applications.

Theoretically, by imposing health certificates as new criteria and limiting the licenses to healthy individuals, the authorities will reduce the risk and spread of zoonotic diseases or the reverse thereof.

The new health certificate requirement might also deter hunters from applying for a hunting license thus may reduce the risk of COVID-19 virus transmission from humans to wild animals.

\section{b) Research Funding}

The World Health Organization has listed the COVID-19 pandemic disease 
as a priority disease for research and development programme (WHO, 2020b). The wildlife ex situ management needs to be included as a national priority field of research. Under the initiatives to save the Malayan Tiger, the DWNP has proposed to establish the Malayan Tiger Research Centre (DWNP, 2020a). The centre shall be the facility for both types of research in situ and ex situ tiger management research, including zoonotic disease research.

To date, the Malayan tiger has been threatened by the two deadly diseases namely the canine distemper disease, a disease that causing brain damage to the infected tiger (Seimon et al., 2013; DWNP, 2019; Sim, 2020) and the newly emerged COVID-19 virus. The unsolved anthropogenic threats and the new zoonotic disease infection have pushed the Malayan Tiger closer to extinction.

The Malayan Tiger is at the crossroads of a population crash. With sufficient grants, the wildlife researchers will be able to work on and find conservation management solutions for the species survival and conservation, including mitigation measures for the COVID-19 pandemic.

In Malaysia, research grants have started to pour in during the movement control order (MCO) period, the Higher Education Ministry has offered special research grants for post-COVID-19 research. It has listed 20 priority areas, including tourism, food security and public health (New Straits Times, 2020).

However, there is no specific grant for wildlife zoonotic disease control management. Additionally, it is recommended that those holding these government grants be allowed to repurpose and realign present grants for immediate use on COVID-19 virus research on wildlife.

Additional COVID-19 research grants should also be given to aspiring researchers in pure sciences, applied sciences, and social sciences to determine the epidemiology and impact of these diseases on local wildlife.

Concurrently, at publication stage of this paper, WHSG (2020) has issued a generalised guidelines on the COVID-19 for management of species of mammals whilst our focus is on local Malaysian scenarios.

\section{Conclusion}

The COVID-19 disease is a global health issue that also affects wildlife. Malaysia must explore preventive measures to curb emerging infectious diseases that would threaten wildlife resources in the country. Control measures must be put in place to better prepare for the next pandemic and post contingency related to zoonotic diseases for better wildlife management and conservation.

The nature of SARS-CoV-2 virus that is capable of reverse zoonotic transmission (zooanthroponosis) has opened a new future dimension of zoonotic disease research. Malaysia must invest by prioritising the zoonotic disease research and build long term emergency preparedness plans to care for local wildlife in their natural habitats in the event of future pandemic outbreaks.

\section{Acknowledgements}

We acknowledge the Centre for Research Innovation Management, Universiti Malaysia Terengganu for the publication grant of this commentary article and Department of Wildlife and National Parks for the access of the information.

\section{References}

Abdullah, M. T. (2016). Evolusi dan biogeografi mamalia Malaysia. Kuala Terengganu: Universiti Malaysia Terengganu.

Abdullah, M. T., Ahmad, A. H., Zainuddin, Z. Z., Chong, J. 1., Kumaran, J. V., Elagupilay, S., Bakar, A. L. A., Japining, J. R. -R., Patah, A. P., Zahidin, M. A., Ramlee, M. N. A., \& Hussin, M. F. (2017). Sixth extinction 
in Malaysia. Paper presented at the Seminar Ekologi Malaysia 2017, Malaysia.

Abdullah, M. T., Edinur, H. A., \& Ten, D. C. Y. (2020). COVID-19 and the emergence of zooanthroponosis. Academic Affairs Quick Update, 50, 1-2, April 2020.

Ahmad, A. H., Payne, J., \& Zainuddin, Z. Z. (2013). Preventing the extinction of the Sumatran rhinoceros. Journal of Indonesian Natural History, 1(2), 11-22.

Andrew, K., Khebir, V., Rozanah, A. A. S., Azizah, D., Badrul, H. A. S., Sarah, D. A., \& Abdul, R. K. (2017). Introduction: One health manual. In K. Abdul Rashid, K. Andrew, V. Khebir, A. H. Rukman, M. Ramlan, S. Razitasham, W. Moniza, \& I. Rosnah (Eds.), One health manual on handling zoonotic disease outbreaks in Malaysia. Serdang, Selangor, Malaysia: National Coordinating Office Malaysia One Health University Network (MyOHUN).

Bittel, J. (2019). Last Sumatran rhino in Malaysia dies. National Geographic, 24 November 2019.

Ceballos, G., Ehrlich, P. R., Barnosky, A. D., García, A., Pringle, R. M., \& Palmer, T. M. (2015). Accelerated modern humaninduced species losses: Entering the sixth mass extinction. Science Advances, 1(5). doi:10.1126/sciadv.1400253

Ceballos, G., Ehrlich, P. R., \& Dirzo, R. (2017). Biological annihilation via the ongoing sixth mass extinction signaled by vertebrate population losses and declines. Proceedings of the National Academy of Sciences of the United States of America, 114(30), E6089-E6096. doi:10.1073/ pnas. 1704949114

Daly, N. (2020). Seven more big cats test positive for coronavirus at Bronx Zoo. National Geographic, 22 April 2020.

DSM. (2020). Demographic statistic first quarter 2020, Malaysia. Retrieved on 15 May 2020 https://www.dosm. gov.my/v1/index.php?r=column/ cthemeByCat $\&$ cat $=430 \&$ bul_id $=a F Y z V j$ J3anNyQytHZGxzcUZxTG9Ydz09\&me nu_id=L0pheU43NWJwRWVSZk1WdzQ 4TIhUUT09.

DWNP. (2008). National Tiger Action Plan for Malaysia. Kuala Lumpur, Malaysia: Department of Wildlife and National Parks Peninsular Malaysia.

DWNP. (2017). Red list of mammals for Peninsular Malaysia Version 2.0. Kuala Lumpur: Department of Wildlife and National Parks.

DWNP. (2018). 2018 Annual Report. Cheras: Department of Wildlife and National Parks.

DWNP. (2019). Status terkini "Awang Besul" Harimau Malaya yang diselamatkan di Kampung Besul Lama, Bukit Besi Dungun, Terengganu on 23 Julai 2019. Retrieved on 16 April 2020 https://harimau.my/amanlahawang-besul-di-sana/

DWNP. (2020a). Initiatives How Can the Community Help? Retrieved from https:// harimau.my/initiatives/. Accessed on 14 May 2020.

DWNP. (2020b). Campaign Save Our Malayan Tiger. Retrieved on 13 May $2020 \mathrm{https} / /$ harimau.my/

FDPM. (2018a). Forestry Department Peninsular Malaysia Annual Report 2017. Kuala Lumpur:

FDPM. (2018b). Bilangan Pelawat ke Hutan Lipur dan Hutan Taman Negeri Mengikut Negeri, 2006-2015. Retrieved on 12 May 2020 http://www.data.gov.my/data/ms $\mathrm{MY} /$ dataset/statistik-pelancong-tamannegara-pahang/resource/36f86a25-c5714937-9712-4a8e41ced211\#

Havmøller, R. G., Payne, J., Ramono, W., Ellis, S., Yoganand, K., Long, B., Dinerstein, E., Williams, A. C., Putra, R. H., Gawi, J., Talukdar, B. K., \& Burgess, N. (2016). Will current conservation responses save the critically endangered Sumatran rhinoceros 
Dicerorhinus sumatrensis? Oryx, 50(2), 355-359. doi:10.1017/S0030605315000472

Kawanishi, K. (2015). Panthera tigris ssp. jacksoni. The IUCN Red List of Threatened Species 2015: e.T136893A50665029. Downloaded 13 June 2017.

Kim, Y.-I., Kim, S.-G., Kim, S.-M., Kim, E.H., Park, S.-J., Yu, K.-M., Chang, J.-H., Kim, E. J., Lee, S., Casel, M. A. B., Um, J., Song, M.-S., Jeong, H. W., Lai, V. D., Kim, Y., Chin, B. S., Park, J.-S., Chung, K.-H., Foo, S.-S., Poo, H., Mo, I.-P., Lee, O.-J., Webby, R. J., Jung, J. U., \& Choi, Y. K. (2020). Infection and rapid transmission of SARS-CoV-2 in ferrets. Cell Host \& Microbe, 27(5), 704-709. doi:https://doi. org/10.1016/j.chom.2020.03.023

Lam, T. T. -Y., Shum, M. H. -H., Zhu, H. -C., Tong, Y.-G., Ni, X.-B., Liao, Y.-S., Wei, W., Cheung, W. Y. -M., Li, W. -J., Li, L. -F., Leung, G. M., Holmes, E. C., Hu, Y. -L., \& Guan, Y. (2020). Identifying SARSCoV-2 related coronaviruses in Malayan pangolins. Nature. doi:10.1038/s41586020-2169-0

Law, Y.-H. (2018). Rare human outbreak of monkey malaria detected in Malaysia, News. Nature, 16 April 2018.

Magintan, D., Traeholt, C., \& Kayal, V. K. (2012). Displacement of the Malayan Tapir (Tapirus indicus) in Peninsular Malaysia from 2006 to 2010. Tapir Conservation, 21, $13-17$.

MyOHUN. (2016). Strategic Plan 2016 -2020. Serdang, Selangor, Malaysia: Malaysia One Health University Network.

New Straits Times. (2020). Higher Education Ministry offers grants for post-Covid-19 research. New Straits Times, 12 April 2020.

NRE. (2010). Department Ensures Survival of Tapir at Sungai Dusun Wildlife Conservation Centre on 7 October 2010 [Press release]. http://www.kats.gov.my/ ms-my/pustakamedia/Kenyataan $\% 20$
Media/Press\%20Statement\%20@\%20\%20 Department\%20Ensures\%20Survival\%20 of $\% 20$ Tapir.pdf

OIE. (2020a). Questions and answers on the 2019 Coronavirus disease (COVID-19). Retrieved on 26 April 2020 https://www. oie.int/en/scientific-expertise/specificinformation-and-recommendations/ questions-and-answers-on-2019novelcoronavirus/

OIE. (2020b). One Health. Retrieved on 15 May $2020 \mathrm{https} / / / \mathrm{www} .0 i \mathrm{i} . \mathrm{int} / \mathrm{en} /$ for-the-media/ onehealth/

Saaban, S., Othman, N., Yasak, M. N., Zafir, A., \& Campos-Arceiz, A. (2011). Current status of Asian elephants in Peninsular Malaysia. Gajah, 35(1), 67-75.

Seimon, T. A., Miquelle, D. G., Chang, T. Y., Newton, A. L., Korotkova, I., Ivanchuk, G., Lyubchenko, E., Tupikov, A., Slabe, E., \& McAloose, D. (2013). Canine distemper virus: An emerging disease in wild endangered Amur Tigers (Panthera tigris altaica). mBio, 4(4), 1-6 doi:10.1128/ mBio.00410-13

Shevade, V., Potapov, P., Harris, N., \& Loboda, T. (2017). Expansion of industrial plantations continues to threaten Malayan Tiger habitat. Remote Sensing, 9(7), 747. doi: $10.3390 /$ rs 9070747

Shi, J., Wen, Z., Zhong, G., Yang, H., Wang, C., Liu, R., He, X., Shuai, L., Sun, Z., Zhao, Y., Liang, L., Cui, P., Wang, J., Zhang, X., Guan, Y., Chen, H., \& Bu, Z. (2020). Susceptibility of ferrets, cats, dogs, and different domestic animals to SARS-coronavirus-2. bioRxiv. doi:10.1101/2020.03.30.015347

Sim, L. L. (2020). The best way to maintain a robust population of wild tigers. The Star, 21 April 2020.

Ta, T. H., Hisam, S., Lanza, M., Jiram, A. I., Ismail, N., \& Rubio, J. M. (2014). First case of a naturally acquired human infection with Plasmodium cynomolgi. Malaria Journal, 13(1), 68. doi:10.1186/1475-2875-13-68. 
Ten, D. C. Y. (2006). Distribution of gaur in Taman Negara. Journal Wildlife and Parks, 23, 1-9.

Ten, D. C. Y., Jani, R., Hashim, N. H., Ellaguipilly, S. T., \& Abdullah, M. T. (in preparation). The readiness of Malaysia incorporating in situ and ex situ conservation to save Malayan Tiger in the wild. European Journal of Wildlife Research.

The Star. (2008). FMD claims rare seladang. The Star, 18 April 2008.

Vellayan, S., Mohamad, A., Radcliffe, R. W., Lowenstine, L. J., Epstein, J., Reid, S. A., Paglia, D. E., Radcliffe, R. M., Roth, T. L., Foose, T. J., Khan, M. K. M., Jayan, V., Reza, S., \& Abraham, M. (2004, 23 - 27 August 2004). Trypanosomiasis (Surra) in the captive Sumatran Rhinoceros (Dicerorhinus Sumatrensis Sumatrensis) in Peninsular Malaysia. Paper presented at the The 11th International Conference of The Association of Institutions for Tropical Veterinary Medicine and 16th Veterinary Association Malaysia Congress, Sunway Pyramid Convention Centre, Petaling Jaya, Malaysia.

WCS. (2020). Update: Bronx Zoo Tigers and Lions Recovering from COVID-19. WCS Newroom, 22 April 2020.

WHO. (2018). Managing epidemics: Key facts about the deadly diseases. Geneva, Switzerland: World Health Organization.

WHO. (2020a). Statement on the second meeting of the International Health Regulations (2005) Emergency Committee regarding the outbreak of novel coronavirus (2019-nCoV). Retrieved on 13 May 2020 https://www.who.int/news-room/detail/3001-2020-statement-on-the-second-meetingof-the-international-health-regulations(2005)-emergency-committee-regardingthe-outbreak-of-novel-coronavirus-(2019ncov).

WHO. (2020b). Prioritizing diseases for research and development in emergency contexts. Retrieved on 12 May $2020 \mathrm{https}: / /$ www. who.int/activities/prioritizing-diseases-forresearch-and-development-in-emergencycontexts.

WHO. (2020c). Coronavirus disease (COVID-19) Situation Report -188. Retrieved on 27 July 2020 https://www. who.int/docs/default-source/coronaviruse/ situation-reports/20200726-covid-19sitrep-188.pdf?sfvrsn=f177c3fa_2

Xiao, K., Zhai, J., Feng, Y., Zhou, N., Zhang, X., Zou, J.-J., Li, N., Guo, Y., Li, X., Shen, X., Zhang, Z., Shu, F., Huang, W., Li, Y., Zhang, Z., Chen, R.-A., Wu, Y.-J., Peng, S.-M., Huang, M., Xie, W.-J., Cai, Q.-H., Hou, F.-H., Chen, W., Xiao, L., \& Shen, Y. (2020). Isolation of SARS-CoV-2-related coronavirus from Malayan pangolins. Nature. doi:10.1038/s41586-020-2313-x

Zhou, P., Yang, X.-L., Wang, X.-G., Hu, B., Zhang, L., Zhang, W., Si, H.-R., Zhu, Y., Li, B., Huang, C.-L., Chen, H.-D., Chen, J., Luo, Y., Guo, H., Jiang, R.-D., Liu, M.-Q., Chen, Y., Shen, X.-R., Wang, X., Zheng, X.S., Zhao, K., Chen, Q.-J., Deng, F., Liu, L.L., Yan, B., Zhan, F.-X., Wang, Y.-Y., Xiao, G.-F., \& Shi, Z.-L. (2020). A pneumonia outbreak associated with a new coronavirus of probable bat origin. Nature, 579(7798), 270-273. doi:10.1038/s41586-020-2012-7 